\title{
The Influence Of Treatment Variation Of Plant Promoting Bacteria In Cultivation On The Quality Of Chinese Cabbage (Brassica rapa L. Ssp. pekinensis)
}

\author{
TRIANI, I G.A.L ${ }^{1 *}$, SOEMARNO ${ }^{2}$, B. T. RAHARDJO ${ }^{3}$ dan E. ZUBAIDAH ${ }^{4}$
}

1) Doctoral Student, Faculty of Agriculture, e-mail : lanitriani@yahoo.com*

2) Department of Soil Science, Faculty of Agriculture

3) Department of Pests and Plant Diseases, Faculty of Agriculture

4) Department of Agricultural Product Technology, Faculty of Agricultural Technology

Brawijaya University, East Java, Indonesia, 65145

Received: July 23, 2020. Revised: August 22, 2020. Accepted: August 24, 2020.

Published: August 25, 2020.

\begin{abstract}
The use of plant promoting bacteria in experimental land in Mayungan village, Tabanan, Bali is an effort to reduce the use of chemicals during Chinese cabbage (Brassica rapa L. Ssp.pekinensis) cultivation.This research was conducted to determine variations in the treatment of plant-promoting bacteria on the quality of Chinese cabbage produced. Chinese cabbage results from variations in the treatment of Plant Growth Promoting Rhizobacteria (PGPR) compared with Chinese cabbage obtained from conventional farmers. This research uses factorial randomized block design with 2 factors. The first factor is the duration of the seeds soaking with PGPR solution namely $0,10,20$, and 30 minutes, while the second factor is the use of PGPR concentrations when watering the plants in the beds (plant age 2 weeks), namely: $0 ; 1.25 ; 2.5$ and $3.75 \mathrm{~cm}^{3} / \mathrm{L}$. Data from laboratory analysis results were analyzed using analysis of variance, then the data analyzed by using the Tukey test at the $5 \%$ level, the data processing using the Minitab17 program. Determination of the best treatment is determined based on the effectiveness index (EI) method. In the treatment variation of the use of PGPR slightly increases the levels of organic matter and Nitrogen, Phosphorus, Potassium of the soil, while the yield and plant height are slightly below Chinese cabbage which derived from conventional farmers. Based on the research results variations in the use of PGPR has the influence on the chlorophyll content, total dissolved solids, texture, brightness levels, but does not has an influence on the vitamin $\mathrm{C}$ in Chinese cabbage. The research results obtained Chinese cabbage with seed soaking for 20 minutes and the use of PGPR when watering plants in the beds equal to $2.5 \mathrm{~cm}^{3} / \mathrm{L}$ is the best result, these results are almost the same as Chinese cabbage from conventional farmers.
\end{abstract}

Keywords-Chinese cabbage, growth-promoting bacteria, quality and treatment.

\section{INTRODUCTION}

Chinese cabbage (Brassica rapa L. Ssp.pekinensis) is one of the food ingredients that is easily obtained and liked by the public. Chinese cabbage which is sold in Bali, precisely in Denpasar City (the provincial capital) comes from Tabanan Regency. Farmers have obstacles during this Chinese cabbage cultivation. In addition to weather and climate factors, the biggest problems faced by farmers during cultivation are pests and plant diseases. The easiest, quickest and most effective solution to overcome plant pest and disease problems is by using pesticides. The type of pesticide that is most widely used by farmers in Bali is insecticide coupled with the use of fungicides. Both types of pesticides are routinely used to treat pests and diseases in horticultural crops.

Pesticides are used in seed production, pre-planting, during crop formation, through crop development and plant maturation to maximize crop yields, quality and customer attractiveness [23]. To overcome the use of chemicals in vegetable cultivation, environmentally friendly technology known as organic farming is applied. Conversion to organic farming illustrates the process of learning and implementation of agricultural change towards sustainable and natural farming. The form of the process varies depending on the local circumstances of the agricultural land [24].

One of the environmentally friendly technologies used in cultivation is to utilize bacteria in the soil. The rhizosphere is a narrow zone of soil that is specifically affected by the root system. The root zone affects microbial populations of about 10 to 100 times, on the competition for nutrients and the presence of species that exhibit a wide range of functional diversity and metabolic flexibility. Rhizosphere soil contains a wide variety of genera of bacteria called rhizobacteria, which exhibit beneficial effects on plant growth. Beneficial and freeliving rhizobacteria are usually referred to as plant growthpromoting rhizobacteria (PGPR). PGPR comes from various genera such as Azospirillum, Azotobacter, Bacillus, Burkholderia, Corynebacterium, Pseudomonas, Rhizobium, Serratia, etc., where Bacillus and Pseudomonas spp. very 
dominant. The function of PGPR is to synthesize certain compounds for plants, facilitate absorption of nutrients from the soil, and reduce or prevent plants from disease [12]. Several studies use PGPR in [8], isolation of different PGPR strain and use it as inoculums for rice grown in pots. As the result occurs a significant increase in inoculated plants than in not inoculated plants. In the research [13] demonstrated that the PGPR strain protected cabbage against black rot and improved growth in greenhouse and field conditions. The PGPR strain can protect from the attacks of Ralstonia solanacearum on tomatoes and Colletotrichum gloeosporioides on cayenne pepper and cucumber. Research [16], on the inoculation of plants with beneficial plant growth promoting bacteria (PGPB), raises a valuable strategy for restoring ecosystems. This study highlights the effects of native PGPB after 1 year inoculation on native shrub growth and rhizosphere composition and activity of microbial communities under drought stress conditions. This study inoculated three semi-arid Mediterranean zone plant species, Thymus vulgaris, Santolina chamaecyparissus and Lavandula dentata with Bacillus thuringiensis strain IAM 12077. The IAM 12077 strain is a sustainable option for restoring degraded soil without damaging and affecting the structure and activity of the microbial community of the rhizosphere in the long term.

Several studies above on the use of growth-promoting bacteria are an effort to reduce the use of chemicals in plant cultivation. The application of environmentally friendly technology with the use of growth-promoting bacteria is something that needs to be done for farmers in Bali, especially all farmers in Mayungan Village, Tabanan, in order to start using natural materials as fertilizers and pesticides towards organic farming. The application of this technology is expected to produce vegetables with almost the same quantity and quality and even better than the yields of conventional farmers. The result of the best quality vegetables at affordable prices is expected to increase the income and welfare of vegetable farmers. As well as research conducted by [18] on, the impact of the increase in rubber prices caused the total household income also increase by 19.309 percent. This means that the economic welfare of farmer households is improved. The increase in income enables the farmer households to spend more income especially for food and nonfood in daily needs.

\section{MATERIAL AND METHOD}

Place and time of the research: This research was carried out in Mayungan and Batunya Villages, Baturiti Subdistrict, Tabanan Regency, Bali. Laboratory analysis was carried out at the Laboratory of the Faculty of Agricultural Technology, Udayana University, Bali, Indonesia and the implementation of this research from August 2018 to June 2019.

Experimental design: The experimental design uses factorial randomized block design with 2 factors. The first factor is the soaking duration the seeds with PGPR solution namely $0,10,20$, and 30 minutes, while the second factor is the use of PGPR concentrations when watering the plants in the beds/bedengan (plant age 2 weeks), namely: $0 ; 1.25 ; 2.5$ and $3.75 \mathrm{~cm}^{3} / \mathrm{L}$. The treatments were grouped into 3 groups so that 48 experimental units were obtained.

Research material: The soil and Chinese cabbage from land in Mayungan Village and conventional farmers in Batunya Village, as well as PGPR obtained from the Plant Pest and Disease Laboratory, Brawijaya University, Indonesia. The chemicals used for the analysis are acetone, sodium phosphate, potassium dichromate, sulfuric acid, ferroin indicator, copper sulfate, sodium hydroxide, hydrochloric acid, boric acid, ammonium hydroxide, ammonium molybdate, and ascorbic acid standards.

Research implementation: Soil before planted with the seeds, conducted fertilization with organic fertilizer (cow/chicken manure). Chinese cabbage seedlings that used amounted to $50 \mathrm{~g}$ and soaked in the $1 \mathrm{~L}$ of PGPR solution. The soaking solution is made of $5 \mathrm{ml}$ PGPR added $1 \mathrm{~L}$ of water, stirring until well blended, then placed in a glass soaking solution made of $5 \mathrm{ml}$ of PGPR is added with $1 \mathrm{~L}$ of water, stirring until well blended, then placed in a glass with each containing $250 \mathrm{ml}$ of solution. $50 \mathrm{~g}$ of seeds, made into 4 parts, each measuring $12.5 \mathrm{~g}$, then put in a glass that contains $250 \mathrm{ml}$ of PGPR solution. Then the immersion was carried out according to the treatment, namely $0,10,20$ and 30 minutes. Seeds of Chinese cabbage soaking results are ready to be sown in the space provided (try pots with fertile soil growing media). In general the seeds grow \pm 7 days, if the seeding process has emerged shoots with a height of $\pm 5 \mathrm{~cm}$, then the shoots are ready to be transferred to the beds that have been prepared for further growth. Age of plants \pm 14 days or after seedlings are in the beds, conducted spraying with PGPR concentrations according to treatment namely 0 ; $1.25 ; 2.5$ and $3.75 \mathrm{~cm}^{3} / \mathrm{L}$, which were applied to plants in the experimental field. The experimental land was made of two beds, one experimental beds plot with the size of $1 \mathrm{~m} \times 6 \mathrm{~m}$, with details of 1 beds containing 4 treatment plots, each treatment plot area namely $1 \mathrm{~m} \times 1.5 \mathrm{~m}$, containing \pm 16 holes which the distance between the rows was $20 \mathrm{~cm}$. An image of the experimental plot layout can be seen in Figure 1. Photos of Chinese cabbage plants on the experimental land can be seen in Figures 2a and 2b.

Data collection: Analysis of organic matter and Nitrogen, Phosphate, Potassium in soils [3], the amount of harvest calculated from experimental land and conventional farmers, Plant height is measured from the base of the stem to the highest leaf tip using a measuring device. Chlorophyll was 
measured using a spectrophotometer with optical density (OD) measurements at wavelengths of 645 and $663 \mathrm{~nm}$ [4]. Vitamin $\mathrm{C}$ is read on a spectrophotometer with a wavelength of $695 \mathrm{~nm}$ [9]. Total dissolved solids were measured by a digital TDS device. For texture and brightness levels is measured using a texture and color analyzer.

Statistical analysis: Laboratory analysis data obtained, then analyzed using analysis of variance (ANOVA), then the data were analyzed by the Tukey test at 5\% level, the data processing using the Minitab 17 program.

Determination of the best treatment is determined based on the effectiveness index (EI) method. The test steps: (1) Rank Attributes in order of decreasing importance, (2) Determine the weighted value of each variable (VW) with relative numbers $0-1$, (3) Determine the normal weight (NW) of each variable by dividing the weight of each variable by the sum of all variable weights, (3) Determine the value of effectiveness (EV) of each variable, with the formula:

$$
\mathrm{EV}=\frac{(\text { Treatment value }- \text { Worst value })}{(\text { Best value }- \text { Worst value })}
$$

Information :

For variables with the greater value the better, then the highest value is used as the best value and the lowest value is used as the worst value. Conversely, for variables with the smaller value the better, the lowest value is used as the best value and the highest value is used as the worst value.

(4) Next, determine the result value with the formula :

$$
\text { Result value }=E V \times N W
$$

(5) The result value of all variables is added up, then the best treatment combination that has the highest result value is selected [1].

\section{RESULTS AND DISCUSSION}

Soil :The soil where the Chinese cabbage cultivated was previously analyzed to determine the state of the soil, and used as a comparison with the land that using PGPR. Soil analysis before and after using PGPR can be seen in Table 1.

In Table 1 shows that after conducted Chinese cabbage cultivation with the use of PGPR obtained a slight increase in levels of organic matter (BO) and levels of N, P, K. This is because after the application of the use of PGPR, bacteria in the soil are more active in absorbing mineral nutrients so that there is a slight increase in the levels of organic matter and $\mathrm{N}, \mathrm{P}, \mathrm{K}$.

The results of the increase in the levels of organic matter and NPK in the soil after the use of variations of the PGPR treatment in the experimental field in Mayungan Village, Bali, are similar to the statement from [11], the use of bacterial fertilizers has made improvements in terms of growth, health and yield of plants. PGPR also supports growth and reduces phytopathogens on yield and growth. The results of PGPR inoculation are strongly influenced by plant age, chemical, physical and biological properties of the soil. Then the future prospects can be a substitute for chemical fertilizers and support ecosystems in Indonesia as one of the conditions for food security. The results of research on increasing phosphate in soil, supported by statements from [20], which isolates phosphate solvent bacteria from the Dipterocarpus alatus root system capable of dissolving higher amounts of $\mathrm{FePO} 4$ and also producing indol-3-acetic acid. Phosphate solvent bacteria isolated from the $D$. alatus root system have beneficial potential in sustainable organic farming systems and reduce agrochemical use in agriculture. PSB isolation was considered important before the use of biological fertilizers in crop production. [19] Research, plants that are symbiotic with mycorrhizal fungi have the ability to absorb nutrients and water higher because of the existence of mycorrhizal fungal hyphae. In addition, mycorrhizal fungi can dissolve phosphate so that the availability of phosphorus in the soil increases. The results of [21] research found that the combination of bokashi fertilizer and arbuscular mycorrhizal fungus can be improved and increase the growth and yield of soybeans in marginal dry land. The combination of bokashi fertilizer at a dose of $15 \mathrm{thaG1}$ with mycorrhizal fungus at a dose of $15 \mathrm{~g} /$ planting hole gave the highest yield namely $1,59 \mathrm{t} \mathrm{haG1}$.

Total harvest: The yield of Chinese cabbage from the variation of PGPR treatment namely 166, while 26 were damaged. Chinese cabbage produced by conventional farmers namely 175, while 17 were damaged. Chinese cabbage cultivation by seed immersion using PGPR treatment and PGPR spraying after planting in the beds, the yield is quite good, the leaves are strong, hard, leaf green color and fresh. Chinese cabbage from the yield of variations in PGPR treatment can be seen in Figure 3 and to see Chinese cabbage from conventional farmers can be seen in Figure 4.

The yields with variations in PGPR treatment are less than yields from conventional farmers, due to pest attacks. The effect of plant-promoting bacteria increases germination, but after the cabbage starts to form leaf segments, the caterpillar starts to attack the Chinese cabbage. On the leaf segments there are a few holes caused by caterpillar bites, but not all leaves are eaten by caterpillars. Chinese cabbage leaf strands look fresh and have the dark green color for the outer strand layer, but for leaf strands inward have the light 
green color. Chinese cabbage from conventional farmers, fewer pest attacks, because insecticide applications are given to overcome these pests, the cabbage produced the outer leaf strands have a dark green color, the inward leaf strands have a green color, the leaves are quite hard, dense and fresh. In accordance with the results of the study of [14] show that the use of biological fertilizers, separately or in combination, increases the germination of Onobrychis sativa L. The results of his research stated that the use of biological fertilizers containing rhizobacteria can be effective in germination and absorption of nutrients. Another important aspect in using microorganisms of rhizobacteria type is the selection of suitable species from each climate, plant type and environmental conditions, because bacteria can have the highest effect on the growth of plant species.

Plant height: The graph of the growth of Chinese cabbage from the use of PGPR and the results of conventional farmers during planting period to harvest (6 observations) can be seen in Figure 5. The Chinese cabbage from the PGPR treatment had a final average height before harvest namely $45 \mathrm{~cm}$, while cabbage from conventional farmers namely $42.50 \mathrm{~cm}$. Observations were carried out by measuring plant height every 7 days, taken from samples of Chinese cabbage plants, each treatment randomly and carried out 3 times measurements, then averaged as height data of Chinese cabbage plants of each treatment.

In Figure 5 it can be seen that the growth of cabbage has increased every observation. However, not all Chinese cabbage with PGPR treatment experience high growth that exceeds the yield of Chinese cabbage produced by conventional farmers, only 10 treatment that higher and the remaining is almost the same growth with Chinese cabbage from the yields of conventional farmers. The results of this growth were supported by research by [7], on the 6th day observation on Brassica juncea $\mathrm{L}$ after planting, there were differences in the root length of the plants in each treatment. The average root length of each treatment namely PF (P. fluorescens) 6,625 cm, BS (B. subtilis) 7,1 cm, PF + BS (P. fluorescens and B. subtilis) $5,735 \mathrm{~cm}$, and control (without treatment) $2,95 \mathrm{~cm}$. This shows that PGPR can stimulate the growth of roots and leaves of cabbage plants. Inoculation PGPR can increase the growth, germination, and harvest of cultivated plants. It is known that PGPR is able to colonize the root surface area and is associated with root plants. Several reports from researchers show that B. subtilis and P. fluorescens have the ability to efficiently master roots and increase crop yields by increasing plant metabolism.

Chlorophyll levels: The results of the analysis of variance showed that the interaction between seed soaking time with PGPR and the use of PGPR when watering the plants in beds had a very significant effect $(\mathrm{P}<0,01)$ on chlorophyll content in Chinese cabbage. Data on chlorophyll content can be seen in Table 2.

Table 2 shows that the highest chlorophyll content was shown in seed immersion time with PGPR for 20 minutes and the use of PGPR when watering plants in beds amounted to $3.75 \mathrm{~cm}^{3} / \mathrm{L}$ namely $101.02 \mathrm{mg} / \mathrm{L}$, while the lowest chlorophyll content was shown in soaking time of the seeds with PGPR for 10 minutes and without the use of PGPR when watering plants in beds namely $27.21 \mathrm{mg} / \mathrm{L}$, which is not significantly different from the seeds soaking time with PGPR for 30 minutes and without the use of PGPR when watering plants in beds namely $28.38 \mathrm{mg} / \mathrm{L}$. This is due to the application of PGPR on seeds before planting namely soaking from 10-30 minutes and application of PGPR watering on Chinese cabbage when it is already planted on beds amounted to $1.25-3.75 \mathrm{~cm}^{3} / \mathrm{L}$ affects on the chlorophyll content produced by Chinese cabbage plants. The research results showed that the average chlorophyll content in Chinese cabbage with PGPR treatment was quite high compared to the yield of Chinese cabbage produced by conventional farmers amounting to $63.74 \mathrm{mg} / \mathrm{L}$. Some Chinese cabbage from PGPR treatment, there are some have higher levels of chlorophyll and some are lower than produced by conventional farmers. This is due to PGPR's performance against pests and diseases and its activities in producing chlorophyll.

The chlorophyll content in leaves is an important parameter for testing plant status, as it is used as an index of photosynthetic potential and plant productivity. In addition, chlorophyll provides an indirect estimate of nutritional status, because a lot of leaf nitrogen is included in chlorophyll. In recent years, chlorophyll is the most important pigment in green plants, not only as a food coloring, but also chlorophyll content as a healthy food ingredient [15]. Mustard plants besides as a source of food, seeds and its seed oil can be used as an herbal medicine. As the results of the evaluation [17], mustard plant is a plant species in the genera of Brassica and Sinapis, in the family of Brassicaceae. Its scientific name is Brassica. Mustard seeds are the small round seeds of various mustard plants, (2) The seeds are usually about 1 to 2 millimetres (0.039 to 0.079 in) in diameter and may be colored from yellowish white to black. Black mustard seed is used for causing vomiting, relieving water retention (edema) by increasing urine production, and increasing appetite.

Vitamin $\mathbf{C}$ :The results of the analysis of variance showed that the interaction between seed immersion time with PGPR and the use of PGPR when watering plants in beds had an effect but not significant $(\mathrm{P}<0.01)$ on vitamin $\mathrm{C}$ levels in Chinese cabbage. Data on vitamin $\mathrm{C}$ levels can be seen in Table 3.

Table 3 shows that the highest level of vitamin $\mathrm{C}$ was 
shown in the soaking time of seeds with PGPR for 20 minutes and the use of PGPR when watering plants in beds amounted to $2.5 \mathrm{~cm}^{3} / \mathrm{L}$ namely $257.93 \mathrm{mg} / 100 \mathrm{ml}$, while the lowest levels of vitamin $\mathrm{C}$ indicated on the immersion time of seeds with PGPR for 30 minutes and the use of PGPR when watering plants in beds amounted to $1.25 \mathrm{~cm}^{3} / \mathrm{L}$ namely $124.98 \mathrm{mg} / 100 \mathrm{ml}$, which is not significantly different from the seeds soaking time with PGPR for 30 minutes and the use of PGPR when watering plants in beds equal to $3.75 \mathrm{~cm}^{3} / \mathrm{L}$ namely $141.75 \mathrm{mg} / 100 \mathrm{ml}$. The results showed the average level of vitamin $\mathrm{C}$ in Chinese cabbage which given PGPR treatment was quite high compared to the yield of Chinese cabbage produced by conventional farmers amounted to $147.93 \mathrm{mg} / 100 \mathrm{ml}$. This is due to the bacterial activity in cabbage which given the PGPR treatment increasing seen from the level of vitamin $\mathrm{C}$ produced is quite high. This statement is in accordance with the research [10], plant growth-promoting bacteria (PGPR) can operate with many physiological, molecular and biochemical pathways. One of the less well-known engagements in this interaction is the role of vitamins. Vitamins can be produced by plants and bacteria. Specifically, during plant-microbial interactions, vitamins (derived from root exudates or produced by rhizosphere bacteria and fungi) can influence PGPB proliferation around the root system. [6] states that plants to get vitamins by maintaining interactions with microbes (in PGPR), in the rhizosphere environment so that vitamins are available. Some bacteria that may play a role in this process are Gluconobacter, Acetobacter, Pseudomonas, and Bacillus megaterium, capable of converting D-glucose, Dsorbitol, or L-sorbose to 2-keto-L-gulonic acid (2-KLGA) in a very efficient pathway, the results can be converted to Lascorbic acid by esterification.

Total dissolved solids: The results of the analysis of variance showed that the interaction between the time of immersion of seeds with PGPR and the use of PGPR when watering the plants in the beds had a significant effect $(\mathrm{P}<0,05)$ on the total dissolved solids in Chinese cabbage. Data on total dissolved solids can be seen in Table 4 .

Table 4 shows that the average total dissolved solids in Chinese cabbage was shown in seeds soaking with PGPR for 10 minutes and the use of PGPR when watering plants in beds amounted to $1.25 \mathrm{~cm}^{3} / \mathrm{L}$ namely $3.25 \%$ brix, while the lowest total dissolved solids were shown on the seeds soaking with PGPR for 30 minutes and the use of PGPR when watering the plants in beds equal to $2.5 \mathrm{~cm}^{3} / \mathrm{L}$ namely $1.55 \%$ brix. The results of this study indicate that the average total dissolved solids in chinese cabbage which given the PGPR treatment is quite high compared to the yield of Chinese cabbage from conventional farmers amounted to $2.03 \%$ brix. Observation of total dissolved solids is useful as an indicator of changes in cabbage as well as related to total acid, wherein the process of maturation there is a progressive increase in total dissolved solids as a result of the transformation of polysaccharides into sugar [22].

Texture:The results of the analysis of variance showed that the interaction between seed soaking time with PGPR and the use of PGPR when watering plants in beds had a very significant effect $(\mathrm{P}<0.01)$ on the texture of Chinese cabbage. Texture data can be seen in Table 5 .

Table 5 shows that the highest mean value of Chinese cabbage texture was shown in seed soaking time with PGPR for 30 minutes and without the use of PGPR when watering the plants in the beds namely $27.42 \mathrm{~kg} \cdot \mathrm{m} / \mathrm{sec}^{2}$, while the lowest value of Chinese cabbage texture was shown without seed immersion and without the use of PGPR when watering plants in beds namely $18.05 \mathrm{~kg} \cdot \mathrm{m} / \mathrm{sec}^{2}$, which is not significantly different from the time of soaking seeds with PGPR for 10 minutes and the use of PGPR when watering plants in beds amounted to $1.25 \mathrm{~cm}^{3} / \mathrm{L}$ namely 18.46 $\mathrm{kg} . \mathrm{m} / \mathrm{sec}^{2}$, and without soaking the seeds with PGPR and the use of PGPR when watering plants in beds as much as 1.25 $\mathrm{cm}^{3} / \mathrm{L}$ namely $19.03 \mathrm{~kg} \cdot \mathrm{m} / \mathrm{sec}^{2}$. The results of this study indicate that the mean texture value of Chinese cabbage which given a PGPR treatment some texture values are rather hard and crispy, the rest harder than the yields of Chinese cabbage from conventional farmers by $27.12 \mathrm{~kg} \cdot \mathrm{m} / \mathrm{sec}^{2}$. The seeds soaking and the use of PGPR solution after planting it in the beds, affect the texture of the Chinese cabbage yields. Some Chinese cabbage textures resulting from PGPR treatment are softer or crunchier than Chinese cabbage on the market. Hardness value indicates the freshness level of fruits and vegetables, but the value of hardness is said to be good not because of high or low values, but depends on the condition of the fruit and vegetables [2]. Plant tissue generally contains more than two thirds of the water, the relationship between the components and water further determines the difference in texture [5].

Brightness levels: The results of the analysis of variance showed that the interaction between the time of seed soaking with PGPR and the use of PGPR when watering the plants in the beds had a very significant effect $(\mathrm{P}<0,01)$ on the brightness levels on Chinese cabbage. Data on the brightness levels can be seen in Table 6 .

Table 6 shows that the highest Chinese cabbage brightness levels is shown in seeds soaking with PGPR for 30 minutes and the use of PGPR when watering plants in beds as much as $3.75 \mathrm{~cm}^{3} / \mathrm{L}$ namely 46.63 ; which is not significantly different from without soaking and without the use of PGPR when watering plants in the beds namely 45.58 and the time of seeds soaking for 30 minutes and the use of PGPR when 
watering plants in the beds amounted to $2.5 \mathrm{~cm}^{3} / \mathrm{L}$ namely 45.97. For the brightness levels in Chinese cabbage, the lowest is shown in the seeds soaking with PGPR for 10 minutes and the use of PGPR when watering plants in beds as much as 2.5 $\mathrm{cm}^{3} / \mathrm{L}$ namely 29.31 . The results of this study indicate that the brightness levelson Chinese cabbage which given the PGPR treatment is less bright (tends to be a bit dim color, but the appearance is fresh) compared to the yields from conventional farmers amounted to 58.11. The PGPR treatment Chinese cabbage does look less bright, the color is more likely to light green, less dark, and more to yellowish-green. According to [5], the bright green colour of leaves and other parts of plants is largely due to the oil-soluble chlorophylls, which in nature are bound to protein molecules in highly organised complexes. When the plant cells are killed by ageing, processing, or cooking, the protein of these complexes is denatured and the chlorophyll may be released. Such chlorophyll is highly unstable and rapidly changes in colour to olive green and brown. This colour change is believed to be due to the conversion of chlorophyll to the compound pheophytin.

The results of the treatment variation effectiveness test of seeds soaking with PGPR solution and the use of PGPR concentrations when watering plants in beds to determine the optimal PGPR use conditions of Chinese cabbage can be seen in Table 7.

Table 7 shows that the effectiveness index (EI) of 16 variations of the PGPR treatment, obtained with the highest value is 0.66. The results of seeds soaking with PGPR solution for 20 minutes and the use of PGPR concentrations when watering plants in beds as much as $2.5 \mathrm{~cm}^{3} / \mathrm{L}$ is the best EI results, then followed by without the PGPR soaking and the use of PGPR concentrations when watering amounted to 1.25 $\mathrm{cm}^{3} / \mathrm{L}$ with EI value namely 0.64 and immersion of seeds with PGPR solution for 20 minutes and use of PGPR concentration when watering $3.75 \mathrm{~cm}^{3} / \mathrm{L}$ with IE value of 0.56 .

\section{CONCLUSION}

In this study it was concluded that variations in the treatment of PGPR use slightly increased the content of organic matter and NPK in the soil, but yields and plant heights were slightly lower compared to yields of conventional farmers. Variations in PGPR treatment significantly affected chlorophyll content, total dissolved solids, texture and brightness levels, but had no significant effect on Vitamin C in Chinese cabbage. The research results obtained Chinese cabbage with seed soaking for 20 minutes and the use of PGPR when watering plants in beds amounted to $2.5 \mathrm{~cm}^{3} / \mathrm{L}$ is the best result with the characteristics of chlorophyll levels: $66.79 \mathrm{mg} / \mathrm{L}$, vitamin C: $257.93 \mathrm{mg} / 100 \mathrm{ml}$, TDS: $2.90 \%$ brix, texture: $24.05 \mathrm{~kg} \cdot \mathrm{m} / \mathrm{sec}^{2}$ and brightness levels: 38.81 .

\section{RECOMMENDATIONS}

Research with the treatment variation in the use of growth-promoting bacteria (PGPR) must be carried out repeatedly, in order to get better quantity and quality than the conventional farmer yields. The application of the PGPR use treatment during vegetable cultivation is an effort to reduce the use of chemical fertilizers and pesticides, in the future this step can reduce environmental pollution.

\section{ACKNOWLEDGMENT}

The author would like to thank the Ministry of Research and Technology, Higher Education for the scholarship in the domestic doctor's program and the farmers who have helped the writer in this research.

\section{References}

[1] E. P. De Garmo, W.G Sullivan and J. R. Canada, Engineering Economy. $7^{\text {th }}$ Ed., Mac Millan Publishing Company: New York, 1984.

[2] ER.B. Pantastico, Fisiologi Pasca Panen, Penanganan dan Pemanfaatan Buah-buahan dan Sayur-sayuran Tropika dan Sub Tropika. Penerjemah : Kamariyani, Gadjah Mada University Press: Yogyakarta, 1989.

[3] AOAC, Method of Analysis : Agricultural, Chemical, Contaminant and Drugs, $15^{\text {th }}$ Edn, Kenneth Helrich, 1990.

[4] G. A. F. Hendry and J..P. Grime, Methods On Comparative Plant Ecology, A Laboratory Manual, Chapman and Hall: London, 1993.

[5] N.P. Singh, Fruit and Vegetable Preservation, $1^{\text {th }}$ Ed., Oxford Book Company 267: Jaipur, India, 2007.

[6] C. Bremus, U. Herrmann, S. Bringer-Meyer and H. Sahm, "The use of microorganisms in L-ascorbic acid production," J Biotechnol 124, 2006, pp. 196-205, doi: 10.1016/j.jbiotec.2006.01.010. PMID: 16516325.

[7] B. Diyansah, L. Q. Aini and T. Hadiastono, "The effect of PGPR (Plant Growth Promoting Rhizobacteria) Pseudomonas fluorescens and Bacillus subtilis On Leaf Mustard Plant (Brassica juncea L.) Infected by TuMV (Turnip Mosaic Virus)," J. Trop. Plant Prot, 1 (1), 2013, pp. $30-38$.

[8] M. A. Ashraf, M. Asif, A. Zaheer, A. Malik, Q. Ali and M. Rasool, "Plant Growth Promoting Rhizobacteria And Sustainable Agriculture: A Review," African Journal of Microbiology Research, 7 (9), 2013, pp. 704-709. DOI: 10.5897/AJMR12.936

[9] R.R.R.Kannan, R. Arumagam, T. Thangaradjou and P. Anantharaman, "Phytochemical Constituents, Antioxidant properties and p-coumaric acid Analysis in some Seagraseses. Fod,” Res Int, 54 (1), 2013, pp. 1229 $-1236$.

[10] O. A Palacios, Y. Bashan and L.E. de-Bashan, "Proven and potential involvement of vitamins in interactions of plants with plant growth-promoting bacteria-an overview," Biol Fertil Soils, 50, 2014, pp. 415-432, doi : 10.1007/s00374-013-0894-3.

[11]R. Kundan, G. Pant, N. Jadon and P.K. Agrawal, "Plant Growth Promoting Rhizobacteria: Mechanism and Current Prospective," J Fertil Pestic, 6 (2), 2015, pp. 1 9, doi : 10.4172/2471-2728.1000155

[12] S. Rawat, and A. Mushtaq,"Plant growth promoting rhizobacteria, a formula for sustainable agriculture: A 
review," Asian Journal of Plant Science and Research, 5 (4), 2015, pp. 43-46, http://www.pelagiaresearchlibrary.com.

[13] K. Liu, C. Garrett, H. Fadamiro, and J. W. Kloepper, "Induction Of Systemic Resistance In Chinese Cabbage Against Black Rot By Plant Growth-Promoting Rhizobacteria," Biological Control Journal, 99, 2016, pp. 8-13, http://dx.doi.org/10.1016/j.biocontrol.2016.04.007.

[14]D. Somayeh, M. Ebrahimi and E. Shirmohammadi, "Influence of plant-growth-promoting bacteria on germination, growth and nutrients' uptake of Onobrychis sativa L. under drought stress. Journal Of Plant Interactions, 12 (1), 2017, pp. 200208,doi:10.1080/17429145.2017.1316527.

[15]S. Gaherwar and P. Kulkarni, "Estimation Of Chlorophyll Content Of Some Green Leafy Vegetables For Their Biochemical Properties. Indian," J.Sci.Res., 13 (2), 2017, pp. 170-171.

[16] E. Armada, M.F.A. Leite, A. Medina, R. Azcon and E. E. Kuramae, "Native bacteria promote plant growth under drought stress condition without impacting the rhizomicrobiome. FEMS Microbiology Ecology, 94, 2018, pp. 1-13, doi: 10.1093/femsec/fiy092.

[17] V. Kumar, S. Pal and B.B Tiwari, "PhytoPharmacological Appraisal of Herbal Crude Drugs," International Journal Of Biology And Biomedical Engineering, 13, 2019, pp. 138 - 148

[18] Y.Erlina, D. Koestiono, N. Hanani, and Syafrial, "The Influence Of Rubber Price Fluctuation On The Performance Of Smallholder Rubber Plantation In Central Kalimantan, Indonesia,"WSEAS Transactions on Business and Economics, 16, 2019, pp. 130-137.

[19]F. Shahzad, H.N. Asghar, Z. Mushtaq, A. Hadayat, N. Zuhra, R. Ahmad and M.A. Ali, "Role Of Endomycorrhizae, Rhizobacteria And Compost To Improve Phosphorus Availability In Onion," Asian J. Agric. Biol., 8(2), 2020, pp. 194-200, doi: 10.35495/ajab.2019.12.553.

[20]Kiriya Sungthongwises, Anan Wongcharoen and Chutinan Choosai, "Phosphate solubilisation and indole acetic acid production by bacteria isolated from root system of Dipterocarpus alatus," Asian J. Plant Sci., 19, 2020, pp. 8-13, doi:10.3923/ajps.2020.8.13.

[21] Sarawa and Halim, "Characteristics Yield of Soybean (Glycine max (L.) Merrill) with Application of Bokashi Fertilizer and Mycorrhiza Fungi on Marginal Dry Lands," Asian J. Crop Sci., 12 (2), 2020, pp. 51-56,doi: 10.3923/ajcs.2020.51.56.

[22]A. Y. Pradhana, "Kajian Penyimpanan Buah Pisang (CV. Mas Kirana) dalam Kemasan Atmosfir Termodifikasi Aktif Menggunakan Kalium Permanganat (Tesis)," M.S. Tesis, IPB, Bogor, Indonesia, 2014.

[23] HAL. Carrot : Strategic Agrichemical Review Process 2011-2014. HAL using the vegetable industry levy and matched funds from the Australian Government. (This project has been funded by HAL using the vegetable industry levy and matched funds from the Australian Government), Australia, 2014.

[24]FAO. Training Manual For Organic Agriculture. Ilka
Gomez and Lisa THIVANT TECA, Team Research and Extension Division (DDNR) of the Food and Agriculture Organization of the United Nation (FAO). 2015.

Creative Commons Attribution License 4.0 (Attribution 4.0 International, CM3 BY 4.0)

This article is published under the terms of the Creative Commons Attribution License 4.0

https://creativecommons.org/licenses/by/4.0/deed.en US 


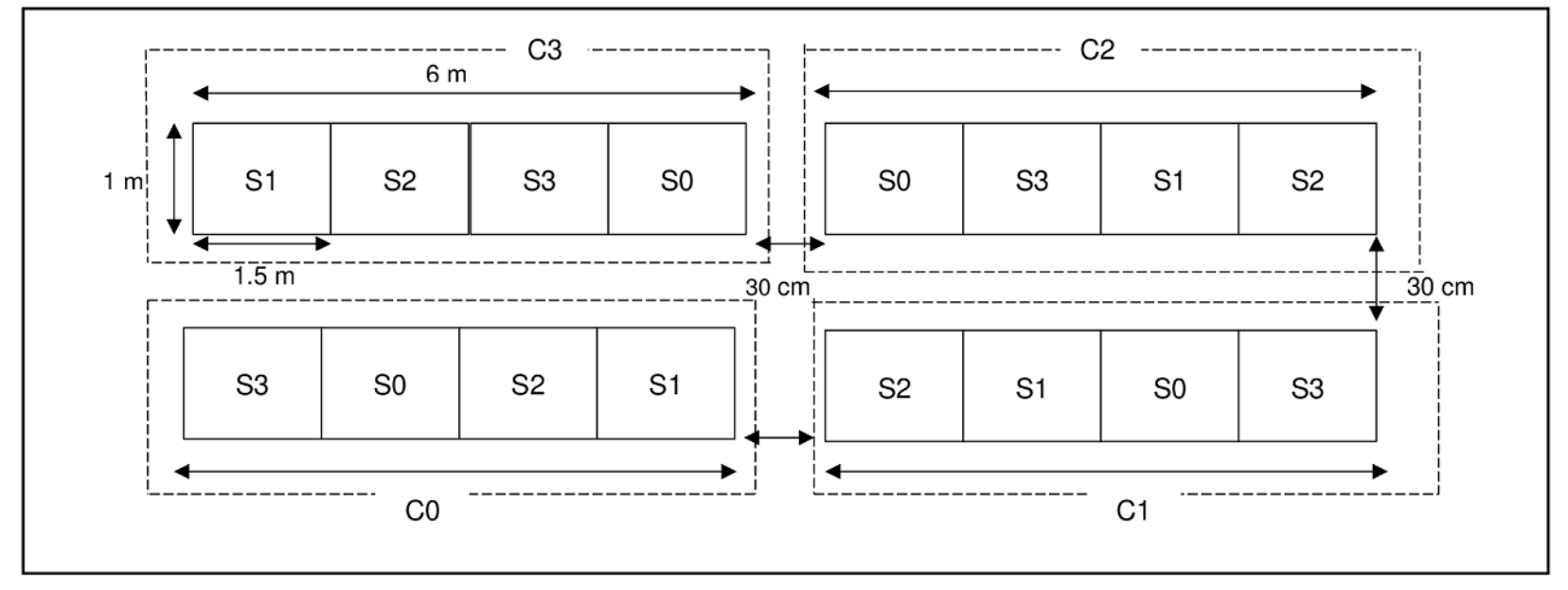

Figure 1. Experiment layout

Information :

1. $\mathrm{S}=$ the soaking duration the seeds with PGPR solution namely $0,10,20$, and 30 minutes (S0, S1, S2, S3)

2. $\mathrm{C}=$ spraying with PGPR concentrations according to treatment namely $0 ; 1.25 ; 2.5$ and $3.75 \mathrm{~cm}^{3} / \mathrm{L}(\mathrm{C} 0, \mathrm{C} 1, \mathrm{C} 2, \mathrm{C} 3)$

3. One experimental bed plot measuring $1 \mathrm{~m} \times 6 \mathrm{~m}$ with details of 1 bed containing 4 treatment plots, each treatment plot measuring $1 \mathrm{~m} \times 1.5 \mathrm{~m}$

4. One treatment plot measuring $1 \mathrm{~m} \times 1.5 \mathrm{~m}$, containing 16 holes with a distance between the rows is $20 \mathrm{~cm}$.

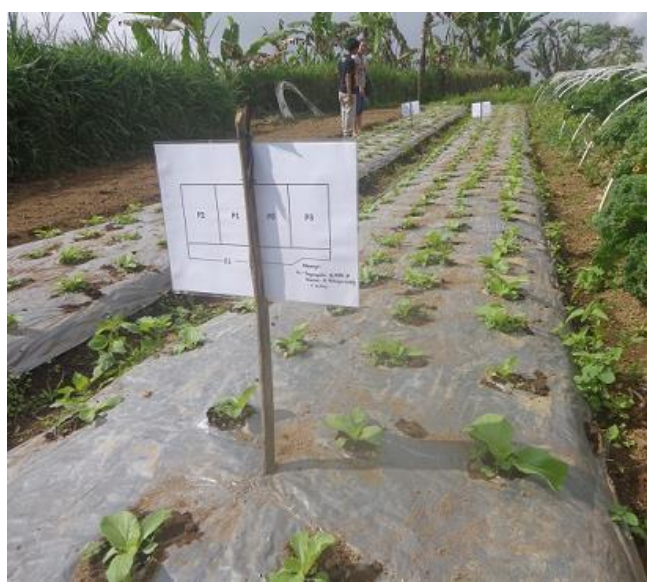

Figure 2a. Photo of Chinese cabbage plant (age \pm 18 days) in the experimental land

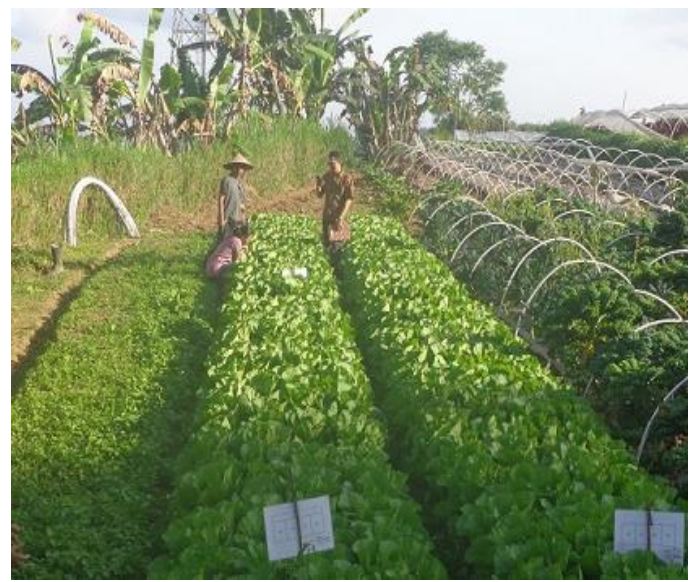

Figure $2 \mathrm{~b}$. Photo of Chinese cabbage plant (age \pm 41 days) in the experimental land 
Table 1. Soil analysis data before and after using PGPR

\begin{tabular}{ccc}
\hline Level & Before & After \\
\hline Organic matter $(\%)$ & 2.87 & 3.45 \\
$\mathrm{~N}(\%)$ & 0.23 & 0.57 \\
$\mathrm{P}(\mathrm{mg} / \mathrm{Kg})$ & 143.79 & 338.54 \\
$\mathrm{~K}(\mathrm{mg} / \mathrm{Kg})$ & 184.24 & 289.15 \\
\hline
\end{tabular}

Source: data from laboratory analysis (2019)

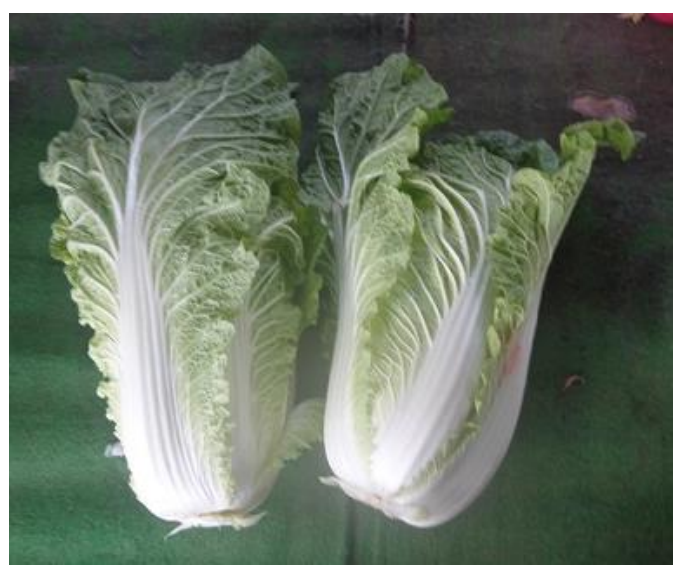

Figure 3. Chinese cabbage from variations in PGPR treatment

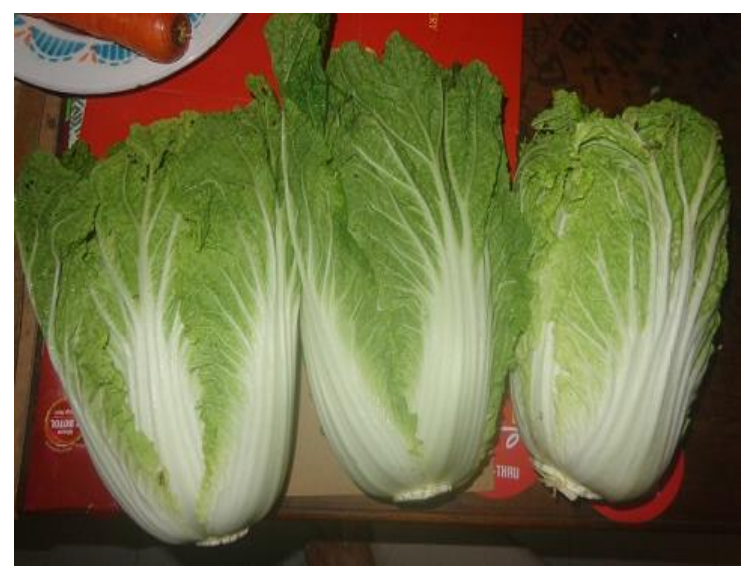

Figure 4. Chinese cabbage from conventional farmers 


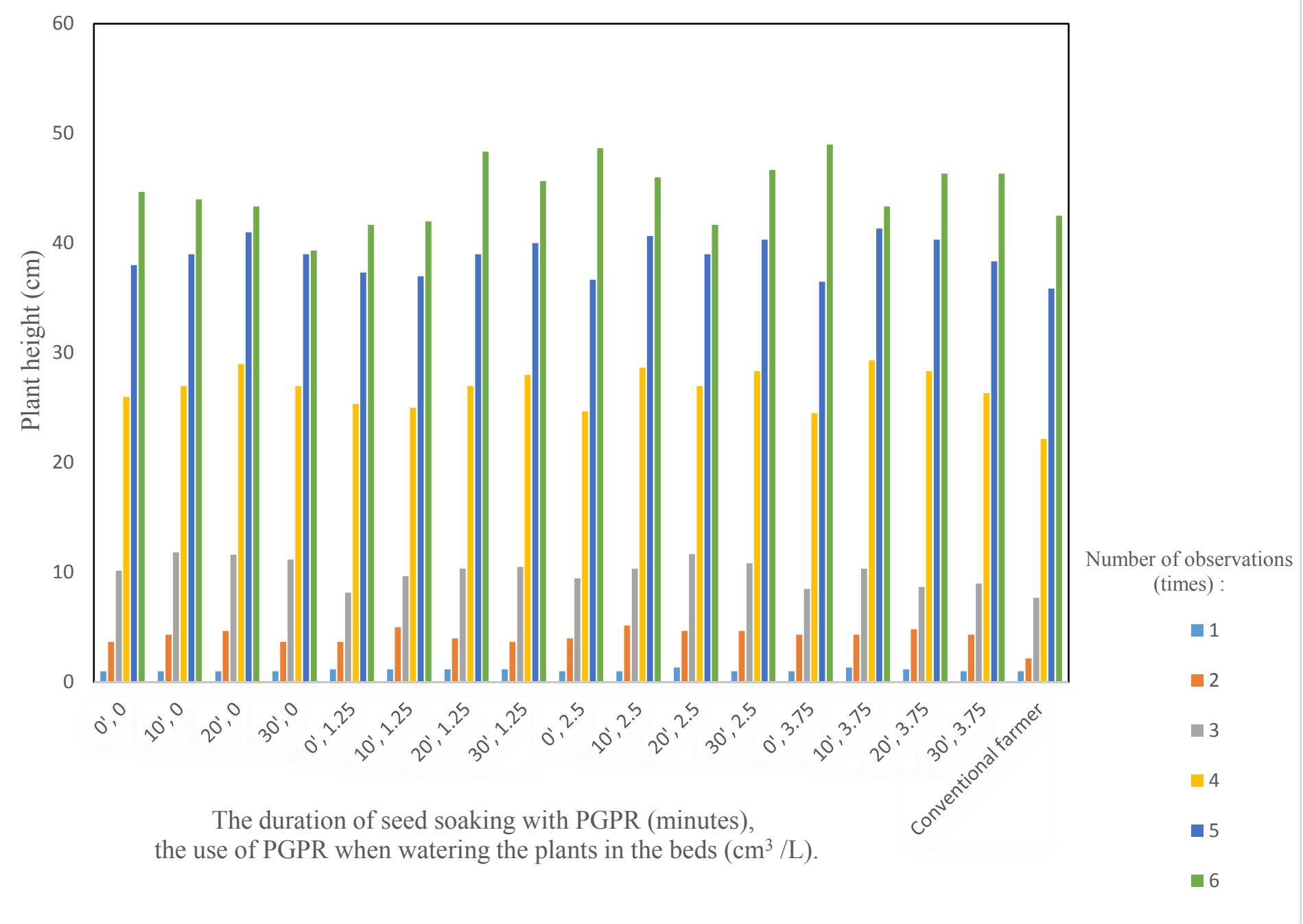

Figure 5. Graph of the cabbage growth with the treatment of PGPR and conventional farmers for 6 times observations 
Table 2. Data on chlorophyll content

\begin{tabular}{ccc}
\hline \multicolumn{2}{c}{ Treatment variation } & Chlorophyll levels \\
Seed soaking time (minutes) & $\begin{array}{c}\text { Concentration of the PGPR use when } \\
\text { watering }\left(\mathrm{cm}^{3} / \mathrm{L}\right)\end{array}$ & $36.73 \mathrm{f}$ \\
\hline 0 & 0 & $27.21 \mathrm{~g}$ \\
10 & 0 & $45.69 \mathrm{e}$ \\
20 & 0 & $28.38 \mathrm{~g}$ \\
30 & 0 & $32.94 \mathrm{fg}$ \\
0 & 1.25 & $51.99 \mathrm{cde}$ \\
10 & 1.25 & $56.13 \mathrm{c}$ \\
20 & 1.25 & $45.63 \mathrm{e}$ \\
30 & 1,25 & $44.73 \mathrm{e}$ \\
0 & 2.5 & $58.13 \mathrm{c}$ \\
10 & 2.5 & $66.79 \mathrm{~b}$ \\
20 & 2.5 & $53.86 \mathrm{~cd}$ \\
30 & 2.5 & $48.77 \mathrm{de}$ \\
0 & 3.75 & $68.5 \mathrm{~b}$ \\
20 & 3.75 & $101.02 \mathrm{a}$ \\
30 & 3.75 & $51.53 \mathrm{cde}$ \\
\hline
\end{tabular}

Information : The mean value followed by different letters shows significantly different results $(\mathrm{P}<0,05)$.

Source: data from laboratory analysis (2019)

Table 3. Data on vitamin C levels

\begin{tabular}{ccc}
\hline \multicolumn{2}{c}{ Treatment variation } & $\begin{array}{c}\text { Vitamin C levels } \\
(\mathrm{mg} / 100 \mathrm{ml})\end{array}$ \\
\hline Seed soaking time (minutes) & $\begin{array}{c}\text { Concentration of the PGPR use } \\
\text { when watering }\left(\mathrm{cm}^{3} / \mathrm{L}\right)\end{array}$ & $167.60 \mathrm{ab}$ \\
10 & 0 & $162.20 \mathrm{ab}$ \\
20 & 0 & $185.90 \mathrm{ab}$ \\
30 & 0 & $151.07 \mathrm{ab}$ \\
0 & 0 & $215.77 \mathrm{ab}$ \\
10 & 1.25 & $191.50 \mathrm{ab}$ \\
20 & 1.25 & $154.95 \mathrm{ab}$ \\
30 & 1.25 & $124.98 \mathrm{~b}$ \\
0 & 1,25 & $201.20 \mathrm{ab}$ \\
10 & 2.5 & $208.40 \mathrm{ab}$ \\
20 & 2.5 & $257.93 \mathrm{a}$ \\
30 & 2.5 & $155.00 \mathrm{ab}$ \\
0 & 2.5 & $185.05 \mathrm{ab}$ \\
10 & 3.75 & $167.85 \mathrm{ab}$ \\
20 & 3.75 & $163.78 \mathrm{ab}$ \\
30 & 3.75 & $141.75 \mathrm{~b}$ \\
\hline
\end{tabular}

Information : The mean value followed by the same letter indicates an insignificant difference $(\mathrm{P}>0,05)$.

Source: data from laboratory analysis (2019) 
Table 4. Data on total dissolved solids

\begin{tabular}{|c|c|c|}
\hline \multicolumn{2}{|c|}{ Treatment variation } & \multirow[b]{2}{*}{$\begin{array}{l}\text { Total dissolved solids } \\
\text { (\% brix) }\end{array}$} \\
\hline Seed soaking time (minutes) & $\begin{array}{l}\text { Concentration of the PGPR use when } \\
\text { watering }\left(\mathrm{cm}^{3} / \mathrm{L}\right)\end{array}$ & \\
\hline 0 & 0 & $1,75 \mathrm{de}$ \\
\hline 10 & 0 & 2.35abcde \\
\hline 20 & 0 & $2.25 \mathrm{bcde}$ \\
\hline 30 & 0 & $2.00 \mathrm{cde}$ \\
\hline 0 & 1.25 & $3.15 \mathrm{ab}$ \\
\hline 10 & 1.25 & $3.25 \mathrm{a}$ \\
\hline 20 & 1.25 & $2.05 \mathrm{cde}$ \\
\hline 30 & 1.25 & $2.00 \mathrm{cde}$ \\
\hline 0 & 2.5 & $2.10 \mathrm{cde}$ \\
\hline 10 & 2.5 & $3.10 \mathrm{ab}$ \\
\hline 20 & 2.5 & $2.90 \mathrm{abc}$ \\
\hline 30 & 2.5 & $1.55 \mathrm{e}$ \\
\hline 0 & 3.75 & 2.50abcde \\
\hline 10 & 3.75 & $2.70 \mathrm{abcd}$ \\
\hline 20 & 3.75 & 2.40abcde \\
\hline 30 & 3.75 & $1.89 \mathrm{de}$ \\
\hline \multicolumn{2}{|c|}{ Yield from conventional farmers } & 2.03 \\
\hline
\end{tabular}

Information : The mean value followed by different letters shows significantly different results $(\mathrm{P}<0,05)$.

Source: data from laboratory analysis (2019)

Table 5. Data on texture

\begin{tabular}{|c|c|c|}
\hline \multicolumn{2}{|c|}{ Treatment variation } & \multirow[b]{2}{*}{ Texture $\left(\mathrm{kg} . \mathrm{m} / \mathrm{sec}^{2}\right)$} \\
\hline Seed soaking time (minutes) & $\begin{array}{l}\text { Concentration of the PGPR use when } \\
\text { watering }\left(\mathrm{cm}^{3} / \mathrm{L}\right)\end{array}$ & \\
\hline 0 & 0 & $18.05 f$ \\
\hline 10 & 0 & $23.53 \mathrm{bcde}$ \\
\hline 20 & 0 & $24.56 \mathrm{bc}$ \\
\hline 30 & 0 & $27.42 \mathrm{a}$ \\
\hline 0 & 1.25 & $19.03 f$ \\
\hline 10 & 1.25 & $18.46 \mathrm{f}$ \\
\hline 20 & 1.25 & $26.71 \mathrm{abc}$ \\
\hline 30 & 1,25 & $24.98 b c$ \\
\hline 0 & 2.5 & $27.08 \mathrm{ab}$ \\
\hline 10 & 2.5 & $21.80 \mathrm{cdef}$ \\
\hline 20 & 2.5 & $24.05 \mathrm{bcd}$ \\
\hline 30 & 2.5 & $27.14 \mathrm{ab}$ \\
\hline 0 & 3.75 & $26.31 \mathrm{abc}$ \\
\hline 10 & 3.75 & $20.88 \mathrm{def}$ \\
\hline 20 & 3.75 & 22.54 bcdef \\
\hline 30 & 3.75 & $22.81 \mathrm{bcdef}$ \\
\hline
\end{tabular}

Information : The mean value followed by different letters shows significantly different results $(\mathrm{P}<0,05)$.

Source: data from laboratory analysis (2019) 
Table 6. Data on brightness levels

\begin{tabular}{ccc}
\hline \multicolumn{2}{c}{ Treatment variation } & Brightness levels \\
\hline Seed soaking time (minutes) & $\begin{array}{c}\text { Concentration of the PGPR use when watering } \\
\left(\mathrm{cm}^{3} / \mathrm{L}\right)\end{array}$ & $45.58 \mathrm{a}$ \\
& 0 & $41.65 \mathrm{abc}$ \\
10 & 0 & $34.41 \mathrm{bcd}$ \\
20 & 0 & $41,37 \mathrm{abc}$ \\
30 & 0 & $44.03 \mathrm{ab}$ \\
0 & 1.25 & $39.52 \mathrm{abc}$ \\
10 & 1.25 & $44.39 \mathrm{ab}$ \\
20 & 1.25 & $39.17 \mathrm{abcd}$ \\
30 & 1.25 & $32.07 \mathrm{~cd}$ \\
0 & 2.5 & $29.31 \mathrm{~d}$ \\
10 & 2.5 & $38.81 \mathrm{abcd}$ \\
20 & 2.5 & $45.97 \mathrm{a}$ \\
30 & 2.5 & $39.42 \mathrm{abc}$ \\
0 & 3.75 & $40.76 \mathrm{abc}$ \\
10 & 3.75 & $39.95 \mathrm{abc}$ \\
30 & 3.75 & $46.63 \mathrm{a}$ \\
\hline
\end{tabular}

Information: The mean value followed by different letters shows significantly different results $(\mathrm{P}<0,05)$.

Source: data from laboratory analysis (2019)

Table 7. The yield values for each of the Chinese cabbage parameters from the treatment variation of seeds soaking with PGPR solution and the use of PGPR concentrations when watering the plants in the beds

\begin{tabular}{|c|c|c|c|c|c|c|c|}
\hline \multicolumn{2}{|c|}{ Treatment } & Seed soaking \\
time (minutes) & $\begin{array}{c}\text { Concentration of the } \\
\text { PGPR use when } \\
\text { watering }\left(\mathrm{cm}^{3} / \mathrm{L}\right)\end{array}$ & $\begin{array}{c}\text { Chlorophyll } \\
\text { levels } \\
(\mathrm{mg} / \mathrm{L})\end{array}$ & $\begin{array}{c}\text { Vitamin C } \\
(\mathrm{mg} / 100 \\
\mathrm{ml})\end{array}$ & $\begin{array}{c}\text { Total } \\
\text { dissolved } \\
\text { solids } \\
(\% \text { brix })\end{array}$ & $\begin{array}{c}\text { Texture } \\
\left(\mathrm{kg} . \mathrm{m} / \mathrm{sec}^{2}\right)\end{array}$ & $\begin{array}{c}\text { Bield value } \\
\text { Levels }\end{array}$ & $\begin{array}{c}\text { (effectiveness } \\
\text { index/EI) }\end{array}$ \\
\hline \multicolumn{2}{|c|}{ Variable weight (VW) } & 0.44 & 0.68 & 0.76 & 0.40 & 0.72 & 3.00 \\
\hline \multicolumn{2}{|c|}{ Normal weight (NW) } & 0.15 & 0.23 & 0.25 & 0.13 & 0.24 & 1.00 \\
\hline 0 & 0 & 0.05 & 0.07 & 0.08 & 0.13 & 0.03 & 0.36 \\
\hline 10 & 0 & 0.06 & 0.06 & 0.15 & 0.10 & 0.11 & 0.48 \\
\hline 20 & 0 & 0.04 & 0.10 & 0.17 & 0.04 & 0.06 & 0.41 \\
\hline 30 & 0 & 0.04 & 0.04 & 0.20 & 0.09 & 0.10 & 0.48 \\
\hline 0 & 1.25 & 0.08 & 0.15 & 0.07 & 0.11 & 0.23 & 0.64 \\
\hline 10 & 1.25 & 0.06 & 0.00 & 0.09 & 0.08 & 0.24 & 0.47 \\
\hline 20 & 1.25 & 0.00 & 0.05 & 0.20 & 0.12 & 0.07 & 0.43 \\
\hline 30 & 1,25 & 0.04 & 0.11 & 0.17 & 0.08 & 0.06 & 0.47 \\
\hline 0 & 2.5 & 0.08 & 0.13 & 0.25 & 0.02 & 0.08 & 0.56 \\
\hline 10 & 2.5 & 0.03 & 0.14 & 0.13 & 0.00 & 0.22 & 0.53 \\
\hline 20 & 2.5 & 0.01 & 0.23 & 0.16 & 0.07 & 0.19 & $\mathbf{0 . 6 6}$ \\
\hline 30 & 2.5 & 0.05 & 0.05 & 0.20 & 0.13 & 0.00 & 0.43 \\
\hline 0 & 3.75 & 0.02 & 0.10 & 0.19 & 0.08 & 0.13 & 0.52 \\
\hline 20 & 3.75 & 0.05 & 0.03 & 0.00 & 0.09 & 0.16 & 0.33 \\
\hline 30 & 3.75 & 0.15 & 0.07 & 0.14 & 0.08 & 0.12 & 0.56 \\
\hline
\end{tabular}

Source: analysis result data (2019) 


\section{Creative Commons Attribution License 4.0} (Attribution 4.0 International, CC BY 4.0)

This article is published under the terms of the Creative Commons Attribution License 4.0

https://creativecommons.org/licenses/by/4.0/deed.en US 